\title{
BUSINESS INTERNATIONALISATION IN THE BASQUE COUNTRY, DOES PUBLIC FINANCING INFLUENCE IN THE RESULTS?
}

\author{
Enara Zarrabeitia Bilbao \\ University of the Basque Country, Spain \\ E-mail: enara.zarrabeitia@ehu.es \\ Izaskun Álvarez Meaza \\ University of the Basque Country, Spain \\ E-mail: izaskun.alvarez@ehu.es
}

Submission: 27/02/2015

Accept: 13/03/2015

\section{ABSTRACT}

Currently, almost all the territories consider the internationalisation of their enterprises as a key enabler to realize their competitiveness, welfare and regional development. However, so far, very few studies have been conducted that analyse the relationship between the internationalisation aids and the degree of internationalisation achieved by a territory. Thus, the objective of this research paper is to analyse the relationships between the internationalisation indicators and the budget expenditure devoted to internationalisation by Basque government. This requires definition of the indicators for assessing the internationalisation, which have been obtained from the Plan for Business Competitiveness 2010-2013 and the Plan for Business Internationalisation 2014-2016 elaborated by Basque Government. Moreover, in order to carry out the research study, the necessary data has been obtained from different Basque and Spanish institutions. After obtaining the data, the estimation method used has been a bivariate correlation analysis that has helped to achieve the target set in the investigation. Results shows that there is a positive relationship between the expenditure on business internationalisation and the main indicators studied, but the same is not true, however, for the degree of openness of the economy and the investment relations with, 
INDEPENDENT JOURNAL OF MANAGEMENT \& PRODUCTION (IJM\&P)

http://www.ijmp.jor.br

v. 6, n. 3, July - September 2015

ISSN: 2236-269X

DOI: 10.14807/ijmp.v6i3.305

foreign countries. The article provides new information on how the government of a small region, such as the Basque Country, perform in relation to the internationalisation policies.

Keywords: Business internationalisation, public funding, internationalisation policies, Basque Country.

\section{INTRODUCTION}

At present, the countries consider their economy, enterprises and people internationalisation as a key driver to achieve their competitiveness, welfare and regional development (AZUA, 2010). Against this background, the progress of internationalisation is probably the most relevant change experimented by the Spanish economy in the second half of the twentieth century. The process has taken place in different stages, driven by the adhesion to the Community project in the eighties and consolidated after the introduction of the single European currency (CONSEJO SUPERIOR DE CÁMARAS, 2007).

The European Union (EU) has worked since its creation for the elimination of trade barriers between member countries, which has led consider Europe as one of the most open markets in the world. However, this openness face today new challenges, such as, the priority access to emerging markets or the opportunities of the single market offers to its members (GOBIERNO VASCO, 2014).

Also, despite the recent and expected strong economic growth for most regions of the world, Western countries, and especially the Europeans, are going through a prolonged structural crisis. In recent years the recession has been remarkable for entrepreneurs, and gradually, they have had to find alternatives to continue developing their businesses. In this situation, one of the best solutions identified has been the export of products and services; because the demand and the prices that cannot be obtained within own borders are being looking at other countries (ORTEGA, 2000).

However, even though the benefits of putting on the market abroad are clear, there are obstacles that end up having more or less importance, depending on the country of destination (SÁNCHEZ, 2012). Thus, throughout this process, the policies to support the internationalisation play an important role. Several studies have proved that without the government support measures a substantial number of 
INDEPENDENT JOURNAL OF MANAGEMENT \& PRODUCTION (IJM\&P)

http://www.ijmp.jor.br

v. 6, n. 3, July - September 2015

ISSN: 2236-269X

DOI: 10.14807/ijmp.v6i3.305

enterprises have not succeeded in internationalisation process (EUROPEAN COMMISSION, 2007; LAMBRECHT; PIRNAY, 2005). Most small and medium-sized enterprises (SMEs), due to the lack of financial resources, time and skills needed for internationalisation, need help to acquire the necessary competences in order to compete successfully in the global market (OECD, 2009; EUROPEAN COMMISSION, 2007).

In this way, the Spanish public administration, aware of the process of economic and commercial liberalisation which involved the creation of Single Market, began to enhance the foreign activity of the Spanish companies in a more active manner from the 1987, through the "Plan of Export Promotion", which has evolved to the present day (VILLARREAL, 2006).

As well, in the case of the Basque Country, according to the plan of competitiveness developed by the Basque Agency for Business Development SPRI ${ }^{1}$ (SPRI, 2010), the internationalisation of enterprises has been one of the strategic objectives of the Basque Government policies. In general, the process of opening to the outside of the Basque economy has been understood from a commercial perspective, promoting the creation of commercial and/or production establishments abroad, the attraction of investment, the establishment of foreign companies in the Basque Country or the technology transfer.

However, although there are policies, programmes and instruments to make easier the process of internationalisation of economies and to improve the external competitiveness of enterprises, there is a scarcity of research studies that analyze the relationship between the policies of internationalisation and the degree of internationalisation achieved by a territory.

The resources that society required to achieve economic and wellbeing development rates are not factors that draw on pages of paper, but there are options about decision that design the present and the future. In all cases, the countries that achieve economic growth rates combined the opportunities offered by global markets

${ }^{1}$ The SPRI group is the business development agency of the Basque Government. The SPRI group manages $75 \%$ of the budget of the Basque Government Department of Economic Development and Competitiveness and ensures that it is distributed through services, programmes, investments and subsidies. 
INDEPENDENT JOURNAL OF MANAGEMENT \& PRODUCTION (IJM\&P)

http://www.ijmp.jor.br

v. 6, n. 3, July - September 2015

ISSN: 2236-269X

DOI: 10.14807/ijmp.v6i3.305

with strategies that mobilize the capacities of internal institutions (GURRUTXAGA, 2010).

In recent decades, in the case of the Basque Country has been considerable effort by the government to support the internationalisation of business and investment attraction. There have been many policies pursued to promote internationalisation, as well as the amount of public investment in this concept. But the scenery is completely different to the revenues obtained from internationalisation; these revenues are far from the amount invested or from the expenditure made (IREKIA, 2014).

However, it would be incorrect to draw conclusions about the need, relevance and return of public expenditure on internationalisation by looking solely and exclusively on the relationship between revenues and expenditures; in this area the administration should not be satisfied or unsatisfied if the amount of the equation were simply positive or negative. After the investment in this area, the following question needs to be raised to measure the degree of satisfaction: Have a higher degree of business internationalisation achieved through the investment?

Therefore, the main objective of the research is to analyze the relationship between public funding for internationalisation and the results obtained in this field.

\section{INTERNATIONALISATION VS. FOREIGN TRADE}

Despite the increasing importance, both in business and academia, of concepts such as internationalisation and foreign trade, even today, there is some controversy about them. Therefore, before proceeding with the present research work, it is considered appropriate to define those terms and to analyze the relationship between them.

Thus, while foreign trade is an ordinary exchange, usually products in exchange for money crossing a "border" (BUSTILLO, 2000), the internationalisation of the enterprise means a lot more than commercialize products and services abroad. In particular, the internationalisation can be defined as a strategy for economic grow through access to new geographic markets, in all domains of the business: sales, purchases, financial aspects and knowledge, among others (DEPARTAMENTO DE INDUSTRIA, INNOVACIÓN, COMERCIO Y TURISMO, 2010). Internationalisation means adapting the processes and procedures of a 
INDEPENDENT JOURNAL OF MANAGEMENT \& PRODUCTION (IJM\&P)

http://www.ijmp.jor.br

v. 6, n. 3, July - September 2015

ISSN: 2236-269X

DOI: 10.14807/ijmp.v6i3.305

company, so that the company can operate in international markets in the same way as in the domestic market.

Nevertheless, foreign trade operations are the evident feature of the business internationalisation. Thus, the interest subjects of researchers, social agents and public institutions are focused on knowing the causes and the conditions of the external balance of goods and services (CONSEJO SUPERIOR DE CÁMARAS, 2007).

\section{INTERNATIONALISATION POLICIES PROMOTED IN THE BASQUE COUNTRY}

In recent decades, in the Basque Country, there have been many public efforts to support business internationalisation and attracting investment; efforts that have contributed to convert the Basque Country in an open economy. Different institutions have wanted to help Basque companies to find their competitive space in the global economy, their "place in the world", considering the differences in the size and the stage of internationalisation of the companies (GOBIERNO VASCO, 2014).

In order to address the challenging task of internationalisation, the Basque public administration has combined different actions to promote the internationalisation. Initial steps have been made to become internationalisation an interest area back to 80s. Accordingly, the creation of an external network of the SPRI, among others, was launched, and it goes on to do its work at present. But, the first Strategic Plan of Foreign Trade Promotion of Basque Enterprises 1993-1996 was the strong support to business internationalisation (CASTILLO; PATÓN, 2010). After this first specific plan, the different industrial policies have identified the internationalisation as a strategic line to improve the competitive position of the industrial company of the Basque Country through the access to new markets and customers. For this reason, the development of different programmes has allowed to support the initiation and consolidation of enterprises internationalisation, to encourage the international vocation, to promote cooperation in the international level and to train persons and organisations on the internationalisation (see table 1). 
INDEPENDENT JOURNAL OF MANAGEMENT \& PRODUCTION (IJM\&P)

http://www.ijmp.jor.br

v. 6 , n. 3, July - September 2015

ISSN: 2236-269X

DOI: 10.14807/ijmp.v6i3.305

Table 1: Internationalisation policies promoted in the Basque Country

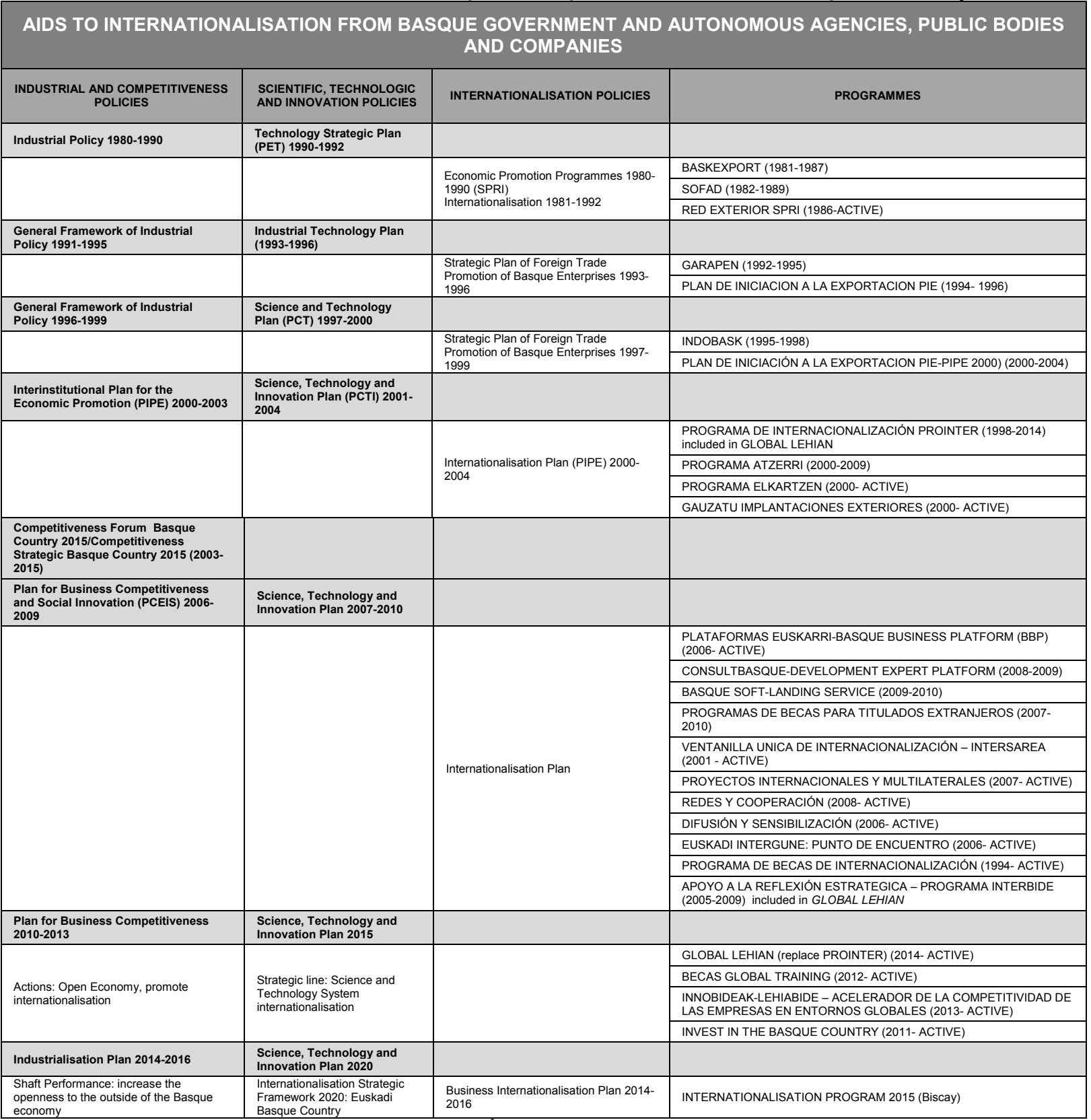

Source: Álvarez et al., 2014.

Moreover, it is note that the last Science, Technology and Innovation Plan (PCTI) 2015 (GOBIERNO VASCO, 2011) marks a shift in the strategic lines related to internationalisation in order to develop new forms of community relationships. For this, the objectives of this plan are oriented to support the internationalisation of the SME and the social economy and to promote the internationalisation of the Scientific and Technological System as a whole which provides added value to productive fabric and is internationally recognized. 
INDEPENDENT JOURNAL OF MANAGEMENT \& PRODUCTION (IJM\&P)

DOI: 10.14807/ijmp.v6i3.305

Also the Business Internationalisation Plan 2014-2016, promoted by the Basque Government, aims to encourage the integration and the international competitiveness of Basque companies, especially SMEs, in the global market. In that sense, the Plan establishes a support framework adapted to the abilities and needs of SMEs in the context of the current crisis, promoting the openness and internationalisation of the Basque economy, strengthening and consolidating foreign trade, contributing to increased Basque implantations abroad and attracting foreign investment to the Basque Country.

\section{THE EVOLUTION OF THE BUSINESS INTERNATIONALISATION IN THE BASQUE COUNTRY}

The external sector liberalisation was an opportunity for businesses and a stability source in the economy as a whole. But, from the statistical point of view, the liberalisation results in an increased difficulty in capturing data that, previously, were collected passively in the administrative records (SANZ, 2002). Therefore, it is necessary to develop new indicators to analyze the behaviour of business internationalisation in recent years in the Basque Country. Thus, Basque Government's Plan for Business Competitiveness 2010-2013 and for Business Internationalisation 2014-2016 have been taken as a reference to define appropriate indicators (exports, degree of openness, exports over GDP, exports to BRICs over GDP, foreign investment in the Basque Country and Basque investments abroad over GDP, number of exporting firms, average exports per firm) to study the evolution of business internationalisation in the Basque Country.

The data obtained show, roughly, that the Basque Country is a small region that has always been aware of the need to open up to the world. However, the positive evolution of some major indicators related to business internationalisation and economy openness were truncated in 2009 due to the economic crisis.

Thus, the behaviour of foreign trade in the Basque Country shows that the positive development, in exports and in imports, was cut short in 2009 (see Figure 1). Furthermore, the degree of openness of the Basque economy reaches its maximum in $2008(59.5 \%)$, shortly before the onset of the economic crisis (see Figure 2). 
INDEPENDENT JOURNAL OF MANAGEMENT \& PRODUCTION (IJM\&P)

http://www.ijmp.jor.br

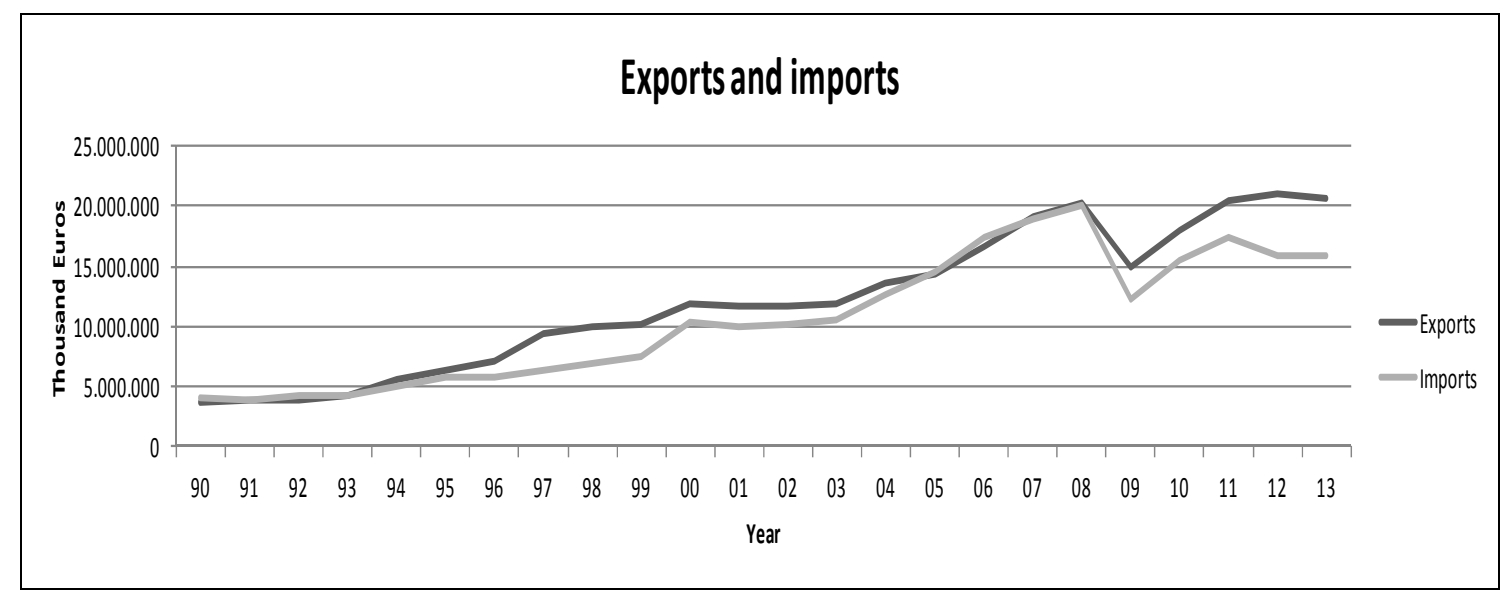

Figure 1: The evolution of good exports and imports in the Basque Country. Source:

Own elaboration based on EUSTAT, 2014a.

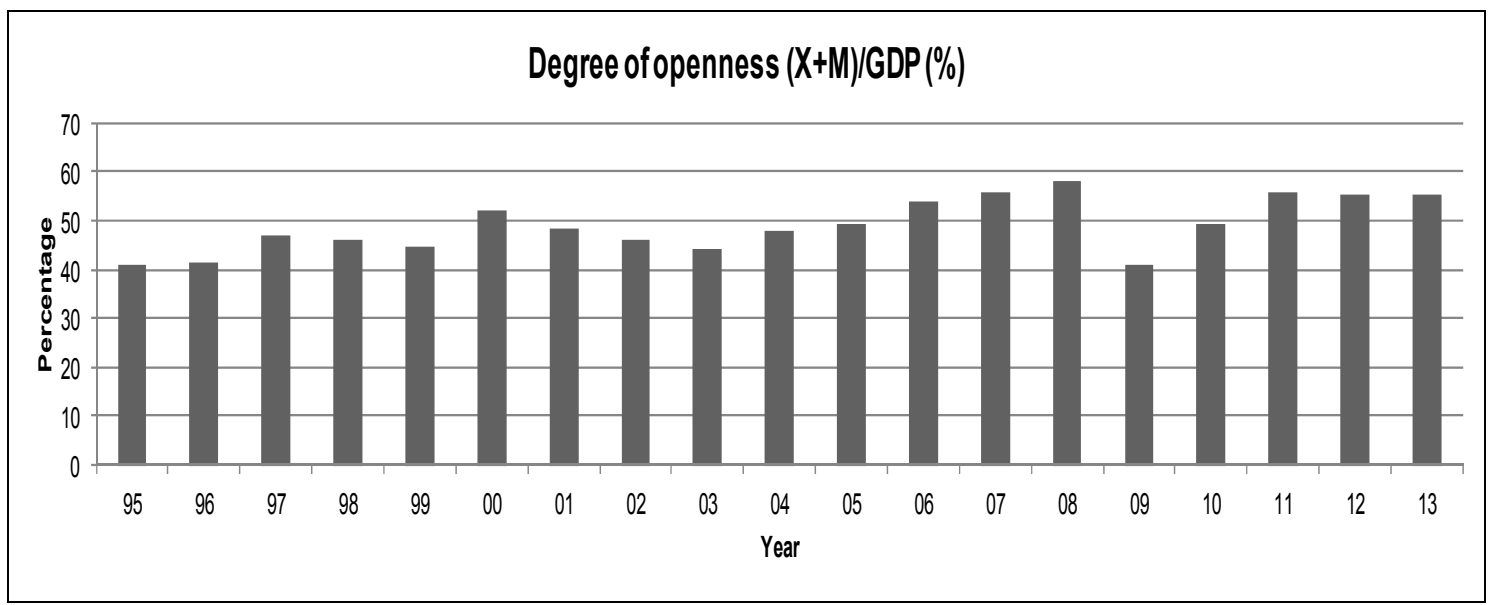

Figure 2: The evolution of the degree of openness in the Basque Country. Source:

Own elaboration based on EUSTAT, 2014a; EUSTAT, 2014b.

In the Figure 3, the evolution of exports over GDP also shows that the upward trend of previous years is truncated in 2009. However, from 2010 it returns to reclaim the positive trend.

If something is currently characterizing the landscape of international market is the emergence in the global economy of a number of emerging markets that are changing at a dizzying rate the economic relations; being the most representative, because of its size and importance, the BRICs (Brazil, Russia, India and China).

In the case of the Basque Country the evolution of exports to BRIC countries over GDP (see Figure 4) has not followed a clear trend in the last two decades. However, also in this case, in 2009 the upward trend that was taking place in previous years is interrupted. However, from 2010 the levels reached are higher than 2008 level. 
INDEPENDENT JOURNAL OF MANAGEMENT \& PRODUCTION (IJM\&P)

http://www.ijmp.jor.br

v. 6, n. 3, July - September 2015

ISSN: 2236-269X

DOI: 10.14807/ijmp.v6i3.305

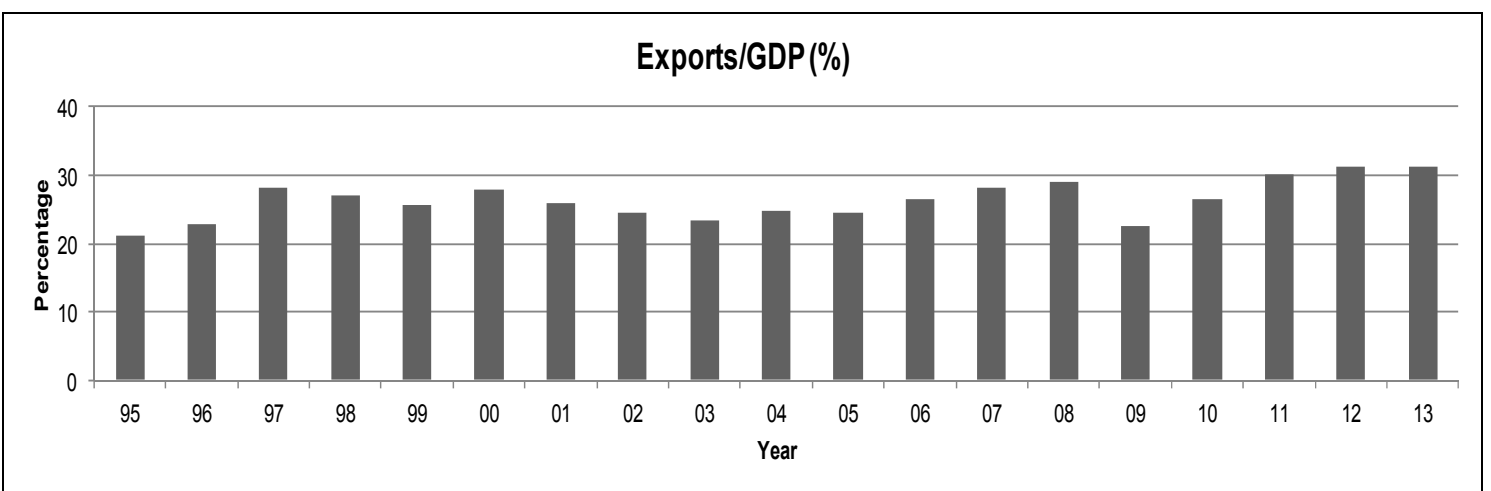

Figure 3: The evolution of good exports over GDP. Source: Own elaboration based on EUSTAT 2014a; EUSTAT, 2014b.

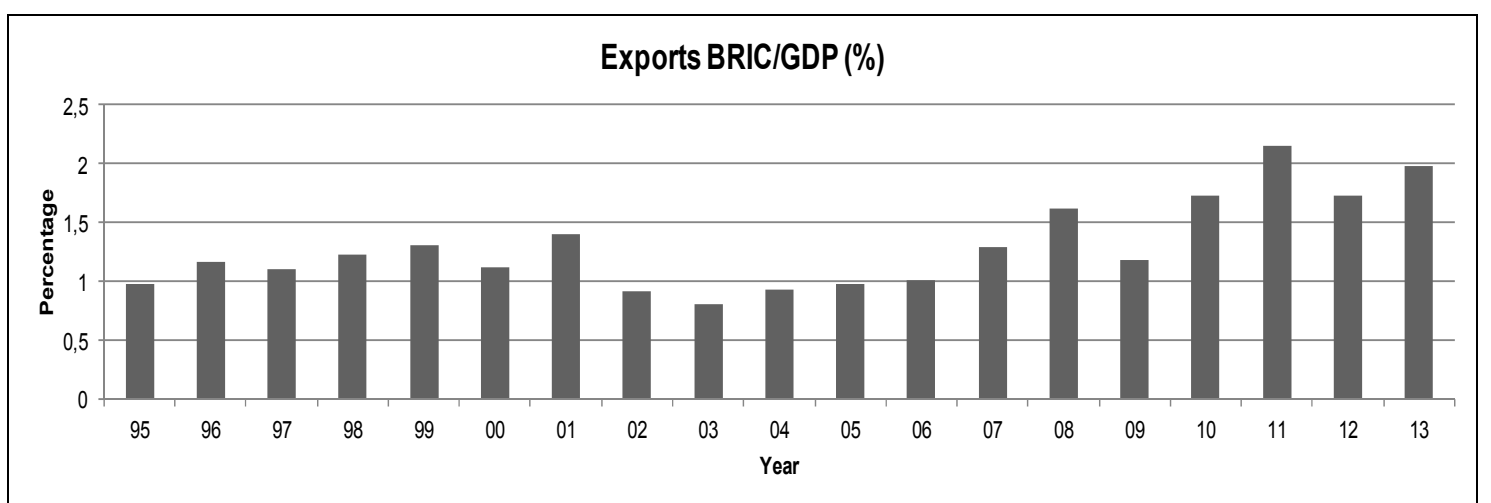

Figure 4: The evolution of good exports to BRIC countries over GDP. Source: Own elaboration based on EUSTAT 2014a; EUSTAT, 2014b.

The analysis of foreign economic relations of the Basque Country also requires the consideration of investment relations with the outside. This is because, on the one hand, the foreign direct investment has acquired such scale that it is impossible to understand much of the current economic dynamics without its consideration; and on the other hand, the foreign investment complements and accompanies the foreign trade as a mechanism for inserting enterprises abroad (ZURBANO, 2006).

However, it is worth noting that the evolution of foreign investment in the Basque Country over GDP and the investments of the Basque Country abroad, show a cyclical behaviour (see Figure 5), being the investments in foreign countries always higher than the investments of foreign countries. Regarding the atypical behaviour of 
INDEPENDENT JOURNAL OF MANAGEMENT \& PRODUCTION (IJM\&P)

http://www.ijmp.jor.br

v. 6, n. 3, July - September 2015

ISSN: 2236-269X

DOI: 10.14807/ijmp.v6i3.305

2007, this is due to the purchase of Scottish Power (UK) by lberdrola ${ }^{2}$ and the purchase of Compass Bank (USA) by BBVA ${ }^{3}$.

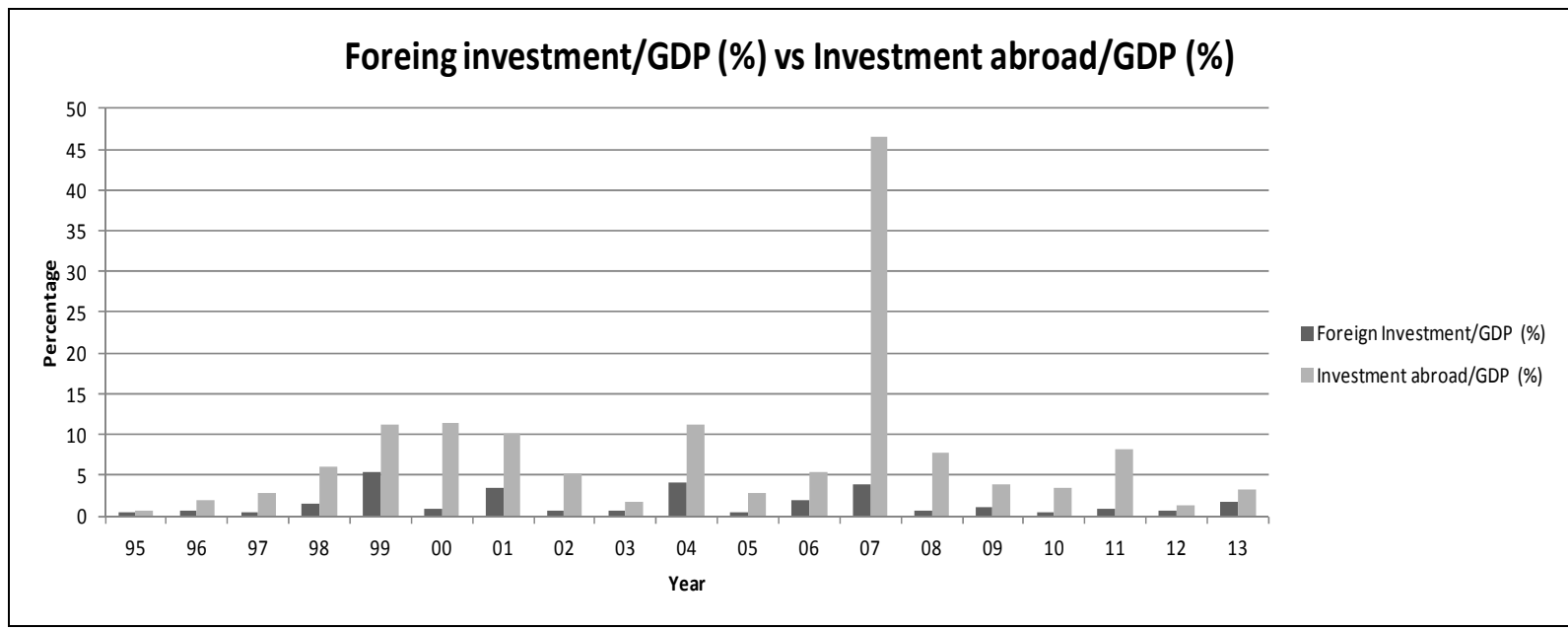

Figure 5: The evolution of foreign investment in the Basque Country and Basque investments abroad over GDP. Source: Own elaboration based on DATAINVEX, 2014; EUSTAT, 2014b.

Finally, figure 6 shows how the number of exporting firms is growing rapidly since 2010. It is noted that due to the phenomenon of globalization and to mitigate the worst effects of the crisis, more and more Basque companies decide to export. However, due to more and more small businesses decide to export, the trend in terms of average exports of companies is the opposite (see Figure 7). Therefore, even though the number of exporting firms has grown in recent years, as well has been observed in previous graphs, the different indicators of foreign trade have not behaved in the same way.

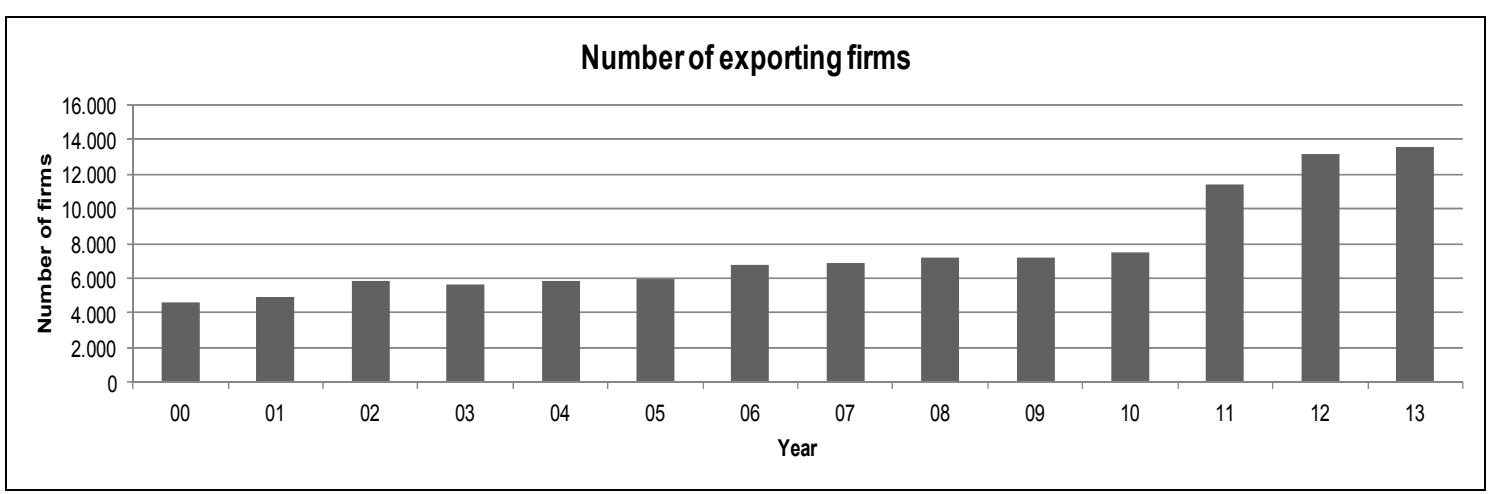

Figure 6: The evolution of the number of Basque exporting firms. Source: Own elaboration based on ICEX, 2014.

\footnotetext{
${ }^{2}$ A public multinational electric utility company based in Bilbao, Basque Country.

${ }^{3} \mathrm{~A}$ multinational banking group based in Bilbao, Basque Country.
} 
INDEPENDENT JOURNAL OF MANAGEMENT \& PRODUCTION (IJM\&P)

http://www.ijmp.jor.br

v. 6, n. 3, July - September 2015

ISSN: 2236-269X

DOI: 10.14807/ijmp.v6i3.305

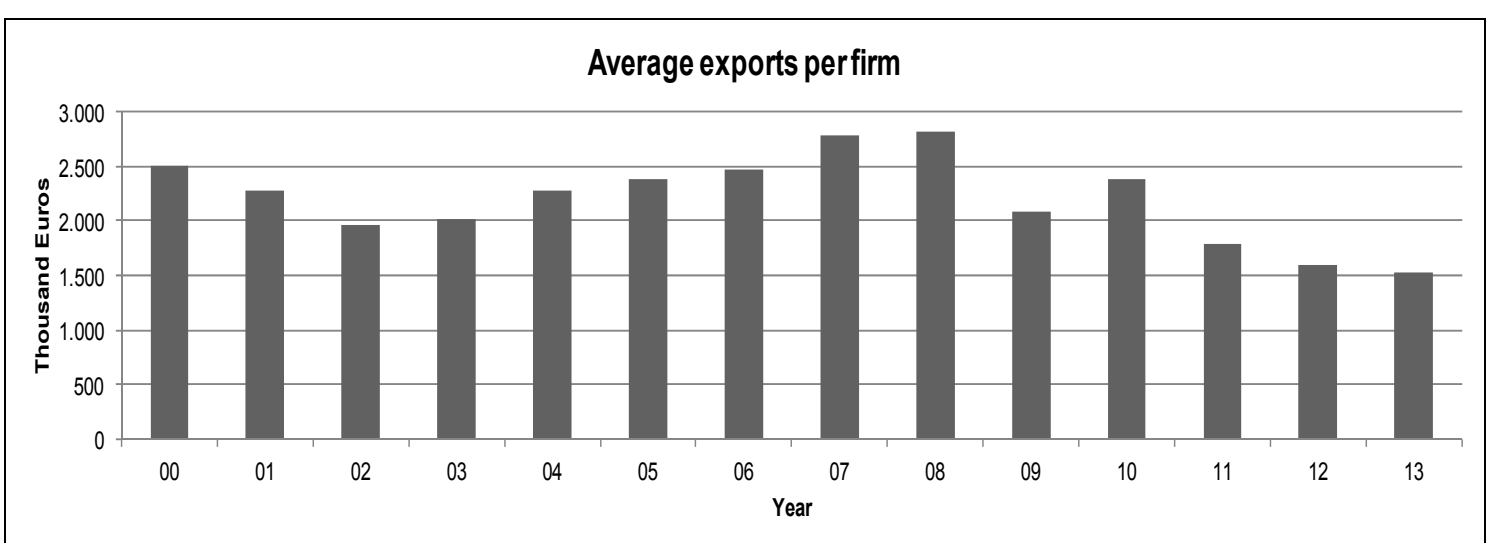

Figure 7: The evolution of the average exports of Basque companies. Source: Own elaboration based on ICEX, 2014.

\section{BUDGET FOR BUSINESS INTERNATIONALISATION IN THE BASQUE COUNTRY}

The budget for business internationalisation in the Basque Country amounted to $22.5 \mathrm{M} €$ in $2014,0.22 \%$ of total budgeted expenditure of the Basque Government.

In this area has also noted the effects of the crisis. Thus, the economic amount addressed to the internationalisation reached its highest level in 2008 (see Figure 8) to fall sharply in 2009. However, even though there was some fluctuation, the trend observed in recent years is recovery. Also, this behaviour is very similar to the evolution of expenditure destined to internationalisation over the total budgeted expenditure in the Basque Country (see Figure 9).

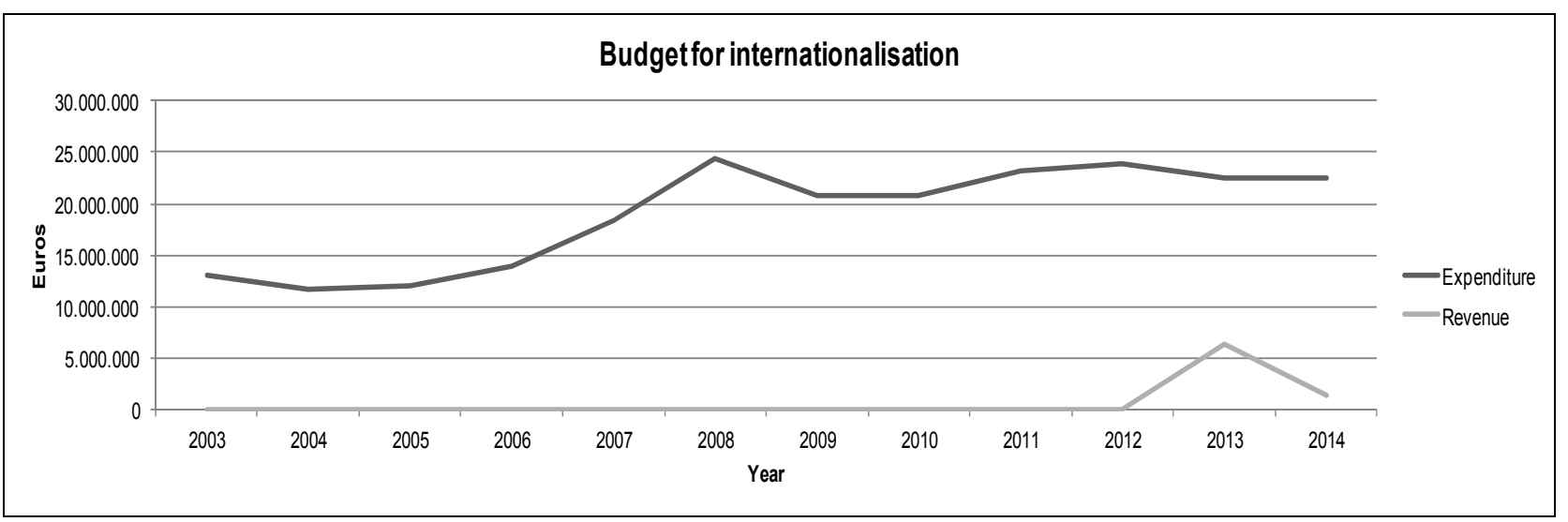

Figure 8: The evolution of the budget for business internationalisation in the Basque Country. Source: Own elaboration based on IREKIA, 2014. 
INDEPENDENT JOURNAL OF MANAGEMENT \& PRODUCTION (IJM\&P)

http://www.ijmp.jor.br

v. 6, n. 3, July - September 2015

ISSN: 2236-269X

DOI: 10.14807/ijmp.v6i3.305

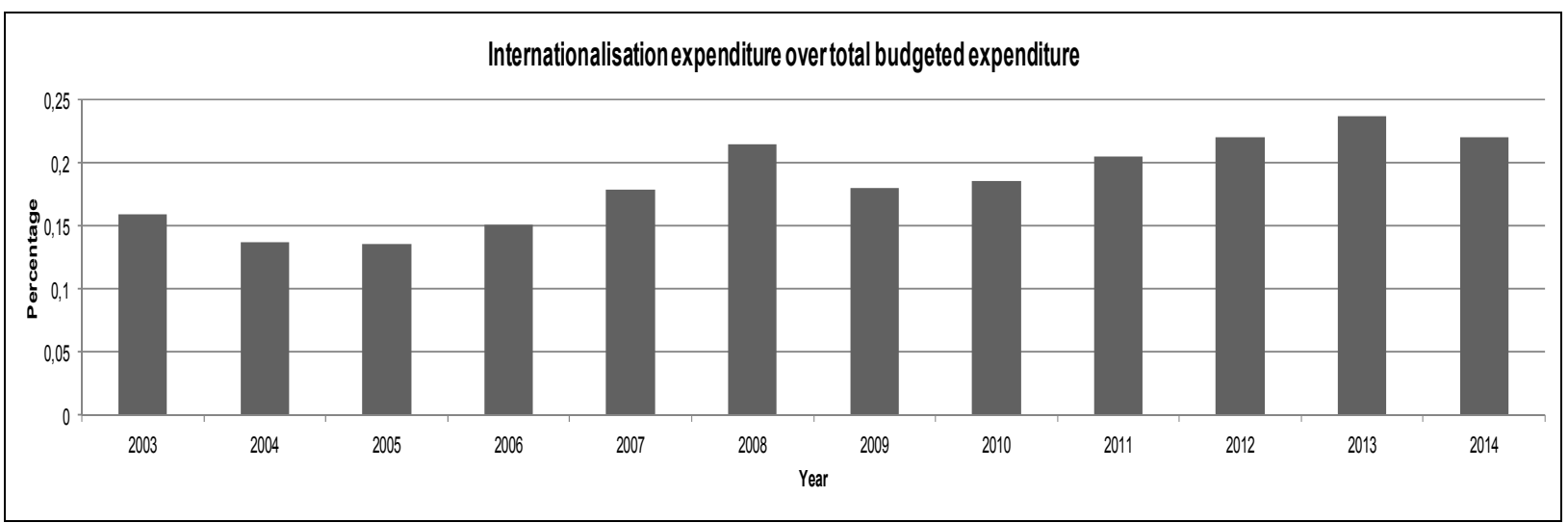

Figure 9: The evolution of expenditure for business internationalisation over total

budgeted expenditure. Source: Own elaboration based on IREKIA, 2014.

Finally it should be noted that most of the expenditure is destined to the concept of "transfers and subsidies current expenses" (see Figure 10).

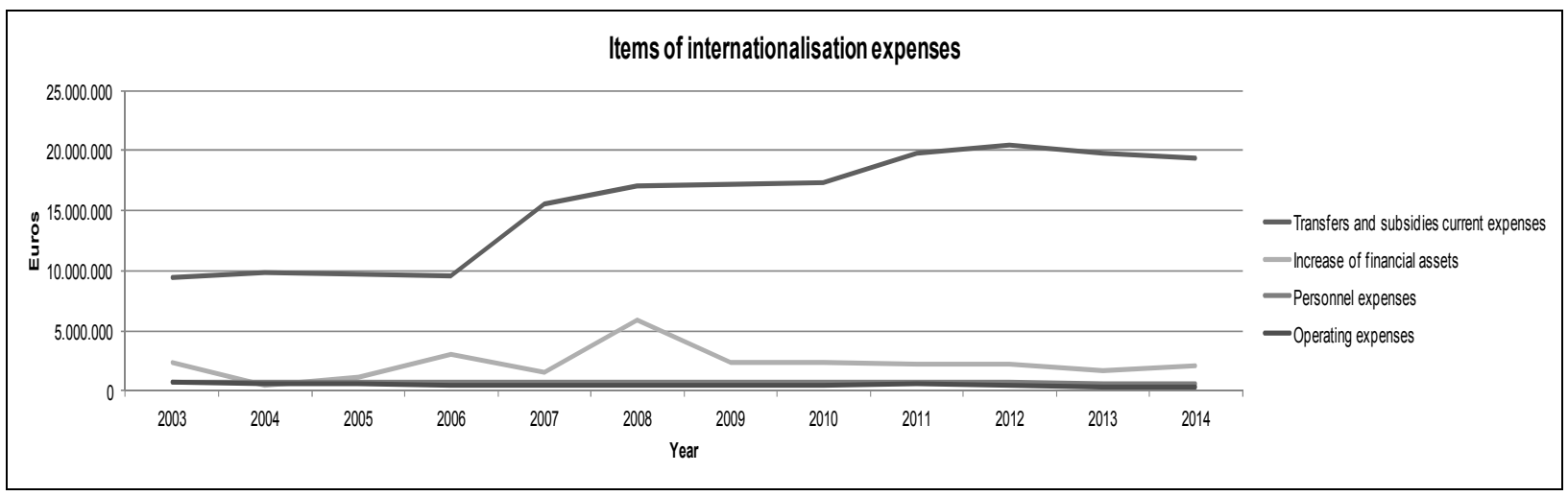

Figure 10: The evolution of the different concepts of expenditure on business

internationalisation in the Basque Country. Source: Own elaboration based on IREKIA, 2014.

\section{RESEARCH METHODOLOGY}

This paper is the result of the research work focused on the study of internationalisation policies relating the foreign trade indicators and the budget allocated to it by the government in the Basque Country. The Basque Country is a region located in northern Spain and it shows a relatively high level of specialization in manufacturing. Furthermore, the report made by European Commission related to Innovation Union Scoreboard 2013 highlights that the Basque Country remains close to the group of countries with high innovation, but 0.06 points below the EU-27 average (EUROPEAN COMMISSION, 2013).

The objective of this research paper is to analyse the relationships between the indicators which characterise internationalisation and the budget expenditure 
INDEPENDENT JOURNAL OF MANAGEMENT \& PRODUCTION (IJM\&P)

http://www.ijmp.jor.br

v. 6, n. 3, July - September 2015

ISSN: 2236-269X

DOI: 10.14807/ijmp.v6i3.305

devoted to internationalisation by Basque public administration. To do this, new indicators have been developed to analyse the behaviour of internationalisation. In this case, Basque Government's Plan for Business Competitiveness 2010-2013 and Business Internationalisation Plan 2014-2016 were taken as a reference to define the studied indicators.

Moreover, in order to carry out the research study, the necessary data has been obtained from four information sources. On one hand, the Statistic Institute of Basque Country (Eustat), Ministry of Industry and Trades and Ministry of Economy and Finance have provided the historical series related to foreign trade in the Basque Country for the period 2003-2013 (EUSTAT, 2014a; EUSTAT, 2014b; DATAINVEX, 2014; ICEX, 2014); and on the other hand, Basque Government has provided the historical series related to the budget expenditure for business internationalisation in the Basque Country.

After obtaining the data, the estimation method used was a bivariate correlation analysis that will achieve the target set in the investigation. Table 2 shows the summary of the variables used.

Table 2: Variables analyzed

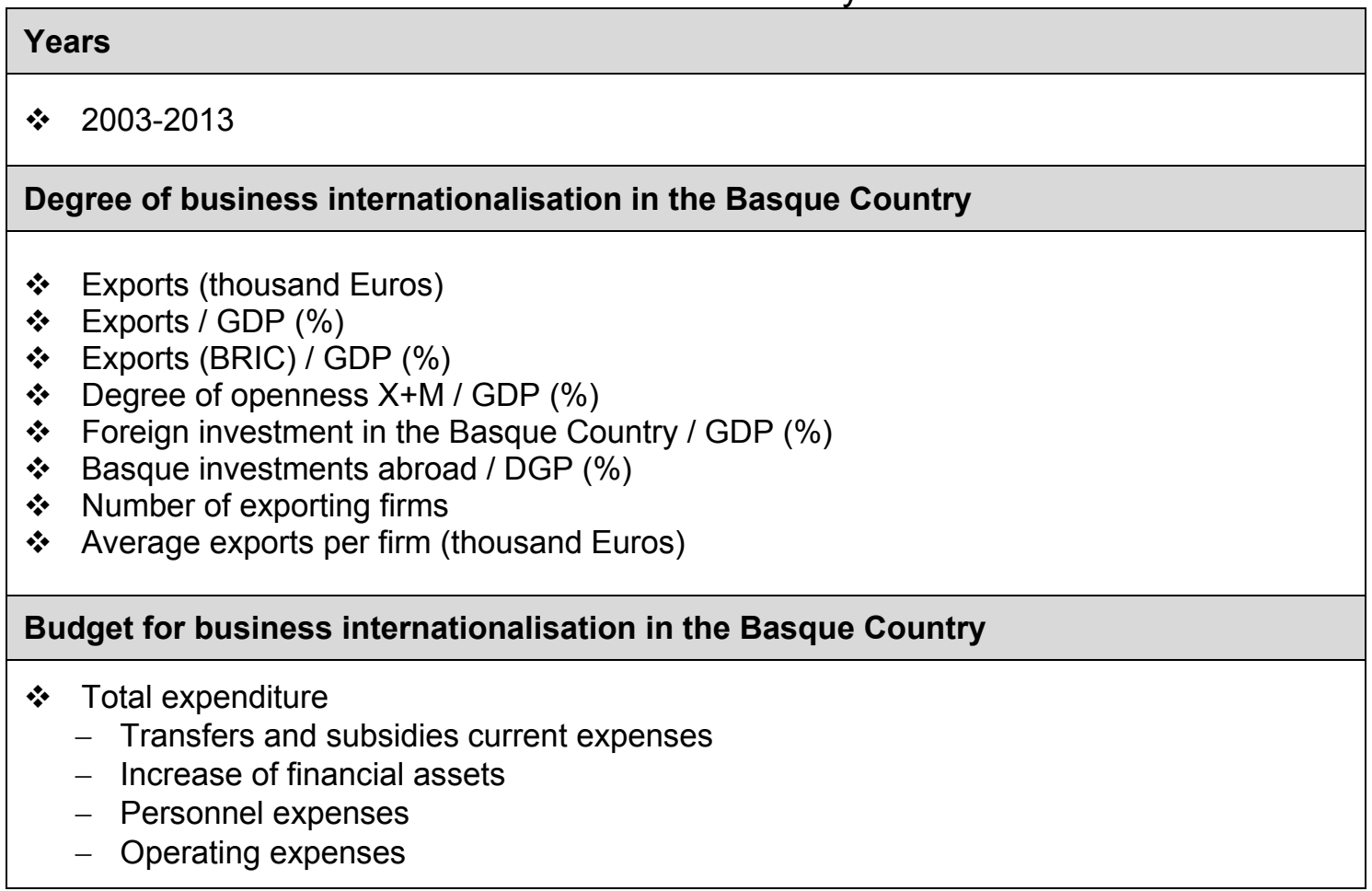

Source: Own elaboration.

\section{RESULTS}

[http://creativecommons.org/licenses/by/3.0/us/]

Licensed under a Creative Commons Attribution 3.0 United States License 
INDEPENDENT JOURNAL OF MANAGEMENT \& PRODUCTION (IJM\&P)

http://www.ijmp.jor.br

v. 6, n. 3, July - September 2015

ISSN: 2236-269X

DOI: 10.14807/ijmp.v6i3.305

The relationship between public funding for internationalisation and the results achieved in this area has been analysed through a bivariate correlation analysis of the different variables studied, precisely through the coefficient of Pearson (see Table 3).

According to the data, on the one hand, total public expenditure on internationalisation is increasing over the years (Pearson 0.879); and on the other hand, as the expenditure increases, so do the following parameters: exports (Euros) (Pearson 0.853); the weight of exports over GDP (Pearson 0.709), in general, and to the countries of the BRIC (Pearson 0.868), in particular; and the number of exporting firms (Pearson 0.711).

Therefore, there is a direct relationship between public funding and the quantity of goods exported, as well as the importance of exports for economic development. Moreover, as was highlighted above, the markets of the BRIC countries constitute the new playing field for Basque companies, and the presence in these countries is directly related to the financial effort made by the Basque government.

However, public expenditure does not show direct relation with the degree of openness of the economy (Pearson 0.478), and neither with investment relations with the outside (Pearson -0.341 and Pearson -0.043). It must be emphasized that these parameters are important for any country because, in general, the higher the degree of openness to the outside and greater the investment relations with the outside economy, better will be its performance (RODRÍGUEZ, 2012). Moreover, it must be emphasized that in the case of the Basque Country there is not a positive relationship along the time between the degree of openness of the economy (Pearson 0.439) and the investment relations (Pearson -0.271 and Pearson -0.148).

Furthermore, although the number of exporting firms increases as public spending increases, not so with the average amount that these companies export (Euros) (Pearson -0.282). Also in this case, as can be seen in table 3, with the increasing of the number of exporting firms decrease the average exports per firm (Pearson -0.766). If this average decrease of exports per firm would be accompanied by the overall decline in exports, this could be related to weak demand. 


\section{INDEPENDENT JOURNAL OF MANAGEMENT \& PRODUCTION (IJM\&P)}

http://www.ijmp.jor.br

v. 6, n. 3, July - September 2015

ISSN: 2236-269X

DOI: 10.14807/ijmp.v6i3.305

Table 3. Correlation analysis between different variables (Pearson coefficients)

\begin{tabular}{|c|c|c|c|c|c|c|c|c|c|c|c|c|c|c|c|}
\hline & & Years & Exp & Exp_GDP & $\begin{array}{c}\text { Exp_BRIC_ } \\
\text { GDP }\end{array}$ & Openness & Foreing_inv & Inv_abroad & No_firms & Exp_firms & $\begin{array}{c}\text { Total } \\
\text { expenditure }\end{array}$ & Tr_sub & I_fin_ass & $\begin{array}{c}\text { Pers_ } \\
\text { expense }\end{array}$ & $\begin{array}{c}\text { Op } \\
\text { expense }\end{array}$ \\
\hline \multirow{2}{*}{ Years } & Correlation & 1 & & & & & & & & & & & & & \\
\hline & Significance & & & & & & & & & & & & & & \\
\hline \multirow{2}{*}{ Exp } & Correlation & ,839" & 1 & & & & & & & & & & & & \\
\hline & Significance & ,001 & & & & & & & & & & & & & \\
\hline \multirow{2}{*}{ Exp_GDP } & Correlation &, $747^{*}$ & ,931" & 1 & & & & & & & & & & & \\
\hline & Significance &, 008 &, 000 & & & & & & & & & & & & \\
\hline \multirow{2}{*}{ Exp_BRIC_GDP } & Correlation & ,924* & ,896" & ,857 & 1 & & & & & & & & & & \\
\hline & Significance &, 000 &, 000 & ,001 & & & & & & & & & & & \\
\hline \multirow{2}{*}{ Openness } & Correlation & 439 & $834^{* *}$ & $878^{* *}$ & ,617 & 1 & & & & & & & & & \\
\hline & Significance & 176 & ,001 &, 000 & ,043 & & & & & & & & & & \\
\hline \multirow{2}{*}{ Foreing_inv } & Correlation &,- 271 &,- 086 &,- 030 &,- 248 & 111 & 1 & & & & & & & & \\
\hline & Significance & ,421 & ,801 & ,930 & ,462 & ,746 & & & & & & & & & \\
\hline \multirow{2}{*}{ Inv_abroad } & Correlation &,- 148 & 175 & 107 &,- 069 & ,313 &, $714^{*}$ & 1 & & & & & & & \\
\hline & Significance & ,663 & ,608 &, 755 &, 840 & ,349 & ,014 & & & & & & & & \\
\hline \multirow{2}{*}{ No_firms } & Correlation & , 888" & ,762 & ,834 & ,858 & ,496 &,- 200 &,- 209 & 1 & & & & & & \\
\hline & Significance &, 000 &, 006 & ,001 & ,001 & 121 &, 556 &, 537 & & & & & & & \\
\hline \multirow{2}{*}{ Exp_firms } & Correlation &,- 540 &,- 176 &,- 336 &,- 451 & ,095 & 272 & ,515 &,- 766 & 1 & & & & & \\
\hline & Significance & ,086 & ,605 & ,313 & 164 & ,781 & ,418 & , 105 & ,006 & & & & & & \\
\hline \multirow{2}{*}{ Total_expenditure } & Correlation & $879^{\prime \prime}$ & $853^{\prime \prime}$ & $709^{4}$ & $868^{\prime \prime \prime}$ & ,478 &,- 341 &,- 043 &, $711^{\circ}$ &,- 282 & 1 & & & & \\
\hline & Significance & , 000 & , 001 & ,014 & ,001 & 137 & ,304 & ,901 & ,014 & ,400 & & & & & \\
\hline \multirow{2}{*}{ Tr_sub } & Correlation & ,942" & ,841" &, 722 & ,908" & ,422 &,- 244 & ,001 & ,803" &,- 426 &, $963^{* *}$ & 1 & & & \\
\hline & Significance & ,000 & , 001 & ,012 & ,000 & 196 & ,471 & ,998 & ,003 & 192 & ,000 & & & & \\
\hline \multirow{2}{*}{ I_fin_ass } & Correlation & 137 & ,367 & 235 & 197 & ,373 &,- 440 &,- 156 &,- 019 & ,355 & 492 & 239 & 1 & & \\
\hline & Significance & 688 & ,267 & ,487 & ,562 & ,259 & 176 & ,646 & ,955 & 284 & 124 & ,479 & & & \\
\hline \multirow{2}{*}{ Pers_expense } & Correlation &,- 079 &,- 132 &,- 266 &,- 031 &,- 268 & ,249 & ,078 &,- 320 & ,305 & ,028 & ,041 &,- 063 & 1 & \\
\hline & Significance & ,817 & ,698 & ,428 & ,928 & ,425 & 460 & ,820 & ,338 & ,362 & ,935 & ,906 & 855 & & \\
\hline \multirow{2}{*}{ Op_expense } & Correlation &,$- 835^{\prime \prime}$ &,- 746 &,$- 604^{*}$ &,$- 679^{*}$ &,- 433 & ,088 &,- 016 &,$- 636^{*}$ & ,214 &,$- 726^{*}$ &,$- 739^{* *}$ &,- 259 & 145 & 1 \\
\hline & Significance & ,001 & ,008 & ,049 & ,022 & 183 & ,798 & ,963 & ,036 & ,528 & ,011 &, 009 & ,442 & 670, & \\
\hline
\end{tabular}

Correlation significant at 0.05 (bilateral)

Years Years from 2003 to 2013

Exp

Exp_GDP Exports / GDP $(\%)$

Exp_BRIC_GDP

Openness

Foreing_inv

Exports / GDP (\%)

Degree of openness $X+M / G D P(\%)$

Foreign investment in the Basque Country / GDP (\%)

Basque investments abroad / DGP (\%)

Inv_abroad

Number of exporting firms

Exp_firms

Average exports per firms (thousand Euros)
Total_expenditure Total expenditure on internationalisation
Tr_sub
Total expenditure on internationalisation Increase of financial assets
Personnel expenses


DOI: 10.14807/ijmp.v6i3.305

But, total exports increase, therefore, to go deeper into this issue, then it would be appropriate to analyse what are the main features of these new Basque exporters who break into the market: what is their size, what is their industry activity, what markets they go, etc.

In the case of the different concepts of the expenditure for business internationalisation in the Basque Country, the highest level, by far, as well it has been studied in the chapter 5, is for "transfers and subsidies current expenses"; and in addition, the influence of this concept on the results of internationalisation is practically the same as in the case of total expenditure. The values of Pearson coefficients are similar for both variables (Total_expenditure and Tr_sub).

The other budget concepts do not show a direct relationship on the positive results related to internationalisation. Concretely, the concepts "increase of financial assets" and "personnel expenses" do not have relationship with the parameters of internationalisation studied, and in the case of the concept "operating expenses" there is an inverse relationship between this expenditure and the results achieved in: exports (Euros) (Pearson -0.746); the weight of exports over GDP (Pearson -0.604), in general, and to the countries of the BRIC (Pearson -0.679), in particular; and the number of exporting firms (Pearson -0.636). However, although this result is very striking, it should be stressed that the "operating expenses" in 2014 have accounted only $1.6 \%$ of the total expenditure for internationalisation (see figure 10 ).

\section{CONCLUSIONS}

The regions with more open economies are those that have higher levels of wealth and welfare. Also, going outside is not an option for a long time, but it has become a need that the level of globalization reached by the world economy has imposed (SÁNCHEZ, 2012).

Thanks to early and continuing commitment of Basque companies by foreign trade since the early $80 \mathrm{~s}$, which has also been supported by the Basque government, the Basque Country is an open economy, exporting in 2013 over 20,000 M€, equivalent to $31 \%$ of GDP. Moreover, during the present economic crisis, exports are still the main driver of the Basque economy; the internationalisation is the best guarantee to diversify risk and improve the overall competitiveness of Basque companies (GOBIERNO VASCO, 2014). 
DOI: 10.14807/ijmp.v6i3.305

This research conclude that there is a positive relationship between public funding for internationalisation and the quantity exported by companies, and the importance of exports for the economic development of a country. Thus, in coming years, the efforts that will expand the export base and will strengthen the international perspective in business strategy and management should be a priority for the Basque government and for the public administration in general.

But, because the importance of internationalisation for the future economic development of countries, and the importance of the aids designated to internationalisation, it is necessary to continue working in this field. This is because despite the importance of financial support for certain indicators related with business internationalisation, it does not exist relationship between this support and the degree of openness and the investment relations with foreign countries.

Moreover, besides the absence of a positive relationship with the budget designated to the internationalisation and the weight that foreign markets has on the economy of the Basque Country and the foreign direct investment received and issued, there is not either a positive trend in the level of these two variables in the last decade. Therefore, it is believed necessary to review the existence or absence of aids in these areas in order to improve them.

Furthermore, it's need to be emphasize that even though the increase of the budget expenditure devoted to internationalisation impulses the exports and the number of exporting firms, that is not the case with the average exports per firm. Besides, it is note that the shortfall between the number of exporting firms and the average exports per firm, which is becoming an interesting new research area analysing what are the characteristics of the new internationalized companies who break into the market in order to identify their weaknesses and to help strengthen the quantity exported by them.

Furthermore, most of the budget expenditure for internationalisation is intended to expenditures on transfers and subsidies; therefore, the influence over the internationalisation parameters of total expenditure and the influence of this particular concept are almost the same. However, despite being very little the budget designated to increase the financial assets and the budget allocated to personnel and operating expenses, is remarkable that there is not a positive relationship 
DOI: $10.14807 / i j m p . v 6 i 3.305$

between these concepts and the results of business internationalisation. Indeed, the relationship is even negative in the case of the operating expenses (institutional communication, advertising). Hence, it is necessary to review these expenditures to improve their performance or to allocate them to other concepts.

Finally, as González et al. (2012) indicate it would be interesting for future researches to identify the different characteristics of exporters that have best weathered the crisis and that have recovered faster, to know what are the keys that should allow a better performance of the export sector in the future. Among others, in order to build a consisting network of the Basque enterprises that internationalise their activities.

\section{REFERENCES}

ALVAREZ, I.; ZARRABEITIA, E.; CANTONNET, M. L.; ALDASORO, J. C. (2014) Foreign Trade of the Basque Country: internationalisation policies. 8th International Conference on Industrial Engineering and Industrial Management, July 23-25, Malaga.

AZUA, J. (2010) La internacionalización de las empresas vascas. La paradoja de su internacionalización en un mundo glokalizado. Realidad y futuro en y desde Euskadi. Available: http://www.basqueinfo.net/wpcontent/uploads/2012/04/GT11_AN_Internazionalizazioa_Azua.pdf. Access:

February 6, 2015.

BUSTILLO, R. (2002) Comercio exterior. Servicio editorial de la Universidad del País Vasco.

CASTILLO, J.; PATÓN, J. (2010) Políticas de promoción y reconversión industrial. Ekonomiaz, n. 25, p. 96-125.

CONSEJO SUPERIOR DE CÁMARAS (2007) Internacionalización de la empresa española. Cooperación empresarial e inversión exterior. Ed. Cámaras de Comercio.

DATAINVEX (2014) Estadísticas de inversiones exteriores. Available: http://datainvex.comercio.es. Access: February 7, 2015.

DEPARTAMENTO DE INDUSTRIA, INNOVACIÓN, COMERCIO Y TURISMO (2010) Plan de competitividad empresarial 2010-2013. Servicio central de publicaciones del Gobierno Vasco, Vitoria.

EUROPEAN COMMISSION (2007) Supporting the internationalisation of SMEs. Directorate-General for Enterprise and Industry. Brussels, Belgium.

EUROPEAN COMMISSION (2013) Innovation Union Scoreboard 2013, European Union, Belgium.

EUSTAT (2014a) Foreing trade. Countries-Annual data. Available:

http://en.eustat.es/bancopx/english/id_2818/indiceRR.html\#axzz3R3tThbJw. Access: February 7, 2015. 
DOI: $10.14807 / i j m p . v 6 i 3.305$

EUSTAT (2014b) GDP and its distribution. Available: http://en.eustat.es/bancopx/english/id_3426/indiceRR.html\#axzz3R3tThbJw. Access: February 7, 2015.

GOBIERNO VASCO (2014) Plan de Internacionalización Empresarial. Available: https://www.euskadi.net/contenidos/informacion/planes_programas_2010/es_planes/ adjuntos/Plan_de_Inter_Emp_es.pdf. Access: February 6, 2015.

GONZÁLEZ, M. J.; RODRÍGUEZ, A.; TELLO; P. (2012) La respuesta de las empresas exportadoras españolas a los cambios del comercio mundial (2008-2010). Boletín Económico del Banco de España, n. 81.

GURRUTXAGA, A. (2010) El sistema de gobernanza en el País Vasco. Ekonomiaz, n. 74, p. 112-131.

ICEX (2014) Perfil de la empresa exportadora española. Available: http://informesestadisticos.icex.es/InformesComerciales/default.jsp?Tipolnforme=1 . Access: February 7, 2015.

IREKIA (2014) Basque Government Budget. Internationalisation. Available: http://aurrekontuak.irekia.euskadi.net/en/programmes/7613/internacionalizacion. Access: February 9, 2015.

LAMBRECHT, J.; PIRNAY, F. (2005) An evaluation of public support measures for private external consultancies to SMEs in the Walloon region of Belgium.

Entrepreneurship and regional development, v. 17, n. 2, p. 89-108.

OECD (2009) Top barriers and drivers to SME internationalisation. OECD, Report by the OECD Working Party on SMEs and Entrepreneurship, Paris.

ORTEGA, A. (2010) La internacionalización de la empresa española y la decisión de exportar como solución a la crisis. Revista de la Facultad de Ciencias Sociales y Jurídicas de Elche, v. 1, n. 6, p. 89-111.

RODRÍGUEZ, C. (2012) Informe socioeconómico de la C.A. de Euskadi 2012. Capítulo 11: Internacionalización. Available:

http://www.eustat.es/elementos/ele0011600/ti_Informe_Socioeconmico_de_la_CA_d e_Euskadi_2012/inf0011667_c.pdf. Access: February 25, 2015.

SÁNCHEZ, N. (2012) Internacionalización. Exportar para sobrevivir. Confebask, n. 1, p. 10-27.

SANZ, A. (2002) Sector exterior español: indicadores de apertura, integración, especialización y competitividad. ICE, n. 798, p. 149-162.

SCHMIELE, A. (2005) Drivers for international innovation activities in developed and emerging countries. Journal of Technology Transfer, n. 37, p. 98-123.

SPRI (2010) Internacionalización. Marco de actuación. Available:

http://www.politicaindustrialvasca.net/PIGV/politicaindustrial_es.nsf/vwPrototipoVista s/774539E54DF4B1CDC1256E90006308B8/\$File/0.0\%20MARCO\%20ACT_Vf.pdf? OpenElement. Access: February 6, 2015.

VILLARREAL, O. (2006) La estrategia de internacionalización de la empresa. Un estudio de casos de multinacionales del País Vasco. Tesis Doctoral, Universidad del País Vasco. 
INDEPENDENT JOURNAL OF MANAGEMENT \& PRODUCTION (IJM\&P)

http://www.ijmp.jor.br

v. 6, n. 3, July - September 2015

ISSN: 2236-269X

DOI: 10.14807/ijmp.v6i3.305

ZURBANO, M. (2006) Informe socioeconómico de la C.A. de Euskadi 2006.

Capítulo 8: Economía. Available:

http://www.eustat.es/elementos/ele0004000/ti_Informe_Socioeconmico_de_la_CA_d e_Euskadi_2006_Economa/inf0004080_c.pdf. Access: February 13, 2015. 